\title{
Film Clips as Classroom Input in an Elective Audio-Visual College English Course in Mainland China
}

\author{
Suiling Liu \\ Dept. of English, University of Macau \\ Rm8003, S2, Postgraduate House, University Avenue \\ University of Macau, Taipa, Macau, 999078 \\ Tel: 853-63550419 E-mail: yb17329@umac.mo
}

Received: September 25, 2016 Accepted: October 31, 2016 Published: November 3, 2016

doi:10.5296/ijele.v4i2.10252 URL: http://dx.doi.org/10.5296/ijele.v4i2.10252

\begin{abstract}
The present study introduces the design of classroom input for an elective Audio-visual College English course in Mainland China with the purpose of developing students' intercultural communicative competence (ICC). Four groups of nineteen film clips in total, chosen from the Intercultural Film Database on four different cultural dimensions, are used as classroom input in the elective College English course, followed by classroom activities like group discussion, pair discussion and role play. Finally, topics for pair and group discussion for each cultural dimension are proposed.
\end{abstract}

Keywords: College English teaching in China, intercultural communicative competence, film clips, cultural dimensions 
1. Intercultural communicative competence (ICC) and College English Teaching in Mainland China

\subsection{Introduction}

As well as language proficiency, ICC is considered a legitimate goal of language teaching (Fantini, 2005; Sercu, 2004). Aguilar (2002) points out the fact that different aspects of ICC have started to be contemplated by the national curricula in different countries, for example, in Japan, England and Wales, Spain, Denmark, the USA and Poland, and foreign language curricula in these countries encourage positive attitudes towards people and cultures related to attitudes of curiosity, openness and tolerance.

Byram (1997, p. 71) defines ICC as "the ability to interact with people from another country and culture in a foreign language". He believes that "people are able to negotiate a mode of communication and interaction which is satisfactory to themselves and the other and they are able to act as mediator between people of different cultural origins" (ibid).

The most widely-adopted model of ICC proposed by Byram (1997) points out the three locations of learning ICC, that is, in the classroom, by fieldwork and through independent learning. However, it is worth pointing out that in China, the location of ICC development is mainly in the classrooms instead of in the other two locations. The reasons are as follows: firstly, the majority of Chinese students, either in high schools or in colleges and universities, do not sojourn (e.g., have a short stay in a country where the target language is spoken), thus fieldwork is impractical. Secondly, even if students in Mainland China search a lot on the internet, they cannot find all that they want to search because of internet restrictions. For example, people in Mainland China cannot use the search engine, Google. Besides, they have very limited access to English television programs or other media, and also the contact with or exposure to people from other countries in daily life is rare. Lack of exposure to a foreign environment deprives Chinese students the opportunity to improve their ICC through independent learning. Thus Chinese students' ICC can be improved only in the English classrooms.

Nevertheless, ICC is emphasized in the curricula of primary and secondary education in Mainland China. For example, in the English Curricula for Senior High School (Experimental Version) (2003) and for Compulsory Education (2011), ICC is both treated as the component and goal of English teaching. However, at the tertiary level, i.e., at college level, the importance of ICC is neglected in English teaching. Despite the fact that intercultural communication and its competence are mentioned in the latest two national College English curricula of the existent seven national curricula, ICC has never been prioritized. In this respect, one local curriculum the Shanghai College English curriculum (2013) is a pioneer, centering on improving students' ICC, intercultural cooperation competence and the ability to be engaged in international communications through English for Specific Purposes (ESP), especially English for Academic Purposes (EAP).

\subsection{Problems of College English Teaching in Mainland China}

As well as the exclusion of ICC in College English teaching in Mainland China, there are 
some other problems of College English teaching. Even if every Chinese college student has already learnt English for more than ten years from primary school to college, it seems that learners of English often have difficulties using it in a real life situation, but are incredibly knowledgeable about English grammar (see Cai, 2014; Liu, 2012; Su, 2013). In 1996, Premier Li Lanqing pointed out that College English teaching in China was time-consuming and inefficient. This claim is supported by an investigation later carried out by the National Language Committee, which finds that around $65 \%$ of college students spend one fourth of their whole study time learning English (Wang, 2007).

Factors behind this "Much-input, Low-outcome" situation of College English, as Premier Li concludes, are multidimensional. Firstly, the purpose of all the national College English curriculum is to make College English teaching uniform throughout China. However, the educational resources of each region are uneven. Thus, the uniformity of the national College English curriculum hinders the development of higher-level colleges and universities, making their College English linger on at a low level; meanwhile, students with poorer English suffer much in order to pass CET4 (Wang \& Wang, 2011). Secondly, the inappropriate teaching objectives and curriculum design are to blame. The number of class hours is insufficient to cover the teaching content. Finally, due to a shortage of English teachers and consequently the large size of College English classes (Hu, 2002), College English classes are likely to be teacher-centered, and class time allocated to each student for classroom practice is very little.

In order to promote the effectiveness of College English teaching, a framework of elective College English courses is proposed by Wen (2012b), composed of modules of General Elective College English and Academic Elective College English. The module of General Elective College English is divided into categories of 'knowledge' and 'skill', in which Listening, Speaking, Argumentation, Presentation, Audio-video courses are recommended (see Table 1). In the present research, Wen's (2012b) recommended Audio-visual Course is chosen with the purpose of cultivating students' ICC.

Table 1. Wen's (2012b) Classification of Elective College English Courses

\begin{tabular}{|l|l|l|l|l|}
\hline & Module & Category & Definition & Recommended courses \\
\cline { 2 - 5 } $\begin{array}{l}\text { Elective } \\
\begin{array}{l}\text { College } \\
\text { English } \\
\text { course }\end{array}\end{array}$ & Knowledge & $\begin{array}{l}\text { Courses that use English to } \\
\text { learn international and Chinese } \\
\text { culture }\end{array}$ & $\begin{array}{l}\text { Courses that aimed to foster } \\
\text { general skills of listening, } \\
\text { speaking, reading, writing, } \\
\text { translating and interpreting }\end{array}$ & $\begin{array}{l}\text { Listening-and-speaking } \\
\text { Course, Reading Course, } \\
\text { Debating course, Public } \\
\text { Speaking, Audio-visual } \\
\text { Course, etc. }\end{array}$ \\
\cline { 2 - 5 } & Skill & $\begin{array}{l}\text { General } \\
\text { academic }\end{array}$ & $\begin{array}{l}\text { Academic courses that are } \\
\text { suitable for students in every }\end{array}$ & \begin{tabular}{l} 
Academic writing \\
\hline
\end{tabular} \\
\hline
\end{tabular}




\begin{tabular}{|l|l|l|l|l|}
\hline \multirow{2}{*}{ Academic } & major & \\
\cline { 3 - 5 } & $\begin{array}{l}\text { Specific } \\
\text { academic }\end{array}$ & $\begin{array}{l}\text { Courses connected to a certain } \\
\text { major }\end{array}$ & $\begin{array}{l}\text { International Law, Mass } \\
\text { Communication, Accounting }\end{array}$ \\
\hline
\end{tabular}

\section{Teaching Materials of an Audio-visual College English Course to Develop Students' ICC}

Teaching materials, according to Brown (1995, p. 139, cited in Matsuda, 2012, p. 169), "the techniques and exercises to be used in classroom teaching". Matsuda (2012, p. 168) points out that what teaching materials bring to foreign language teaching is "a source of input".

The most traditional teaching material for language classroom is the textbook. However, no textbook is used in this course. The teaching materials in the elective Audio-visual College English course are nineteen film clips chosen from the Intercultural Film Database on four different cultural dimensions. In this elective Audio-visual College English course with the aim of developing students' ICC, a communicative approach is adopted. As Corbett suggests, "a full range of communicative activities can be used to serve the goals of an intercultural task" (2003, p. 43), and "an adaptation of task-based communicative activities can well serve the goals of an intercultural curriculum" (ibid, p. 45).

A communicative task, according to Nunan (1989), is composed of goals, input, activities, teacher role, learner role and settings. This framework for analyzing communicative tasks is used as a reference when tasks for the Audio-Visual College English course are designed (see Figure 1).

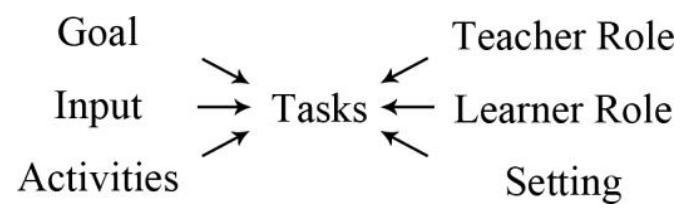

Figure 1. Framework for analyzing communicative tasks (Nunan, 1989, p. 11)

In this context, the teaching goal, besides English proficiency, is related to the ICC development. Classroom input is the four groups of film clips selected from the Intercultural Film Database, which are "the stimulus provided by the teacher for the learning to occur" (ibid, p. 42). Concerning the teacher role, the teacher is not the center in this course. As the course progresses, the teacher mainly acts as an organizer, a facilitator, an observer and an analyst (ibid, p. 42). The crucial role in this course is taken by the students. It is worth pointing out that, as Corbett demonstrates, the learner's role "varies from activity to activity, and from stage to stage within each activity" (2003, p. 43). Gradually learners learn to make their way as a listener and performer, an interactor and negotiator to developing their ICC and finally attain ultimate goal of taking responsibility for their own learning, developing autonomy, skills of learning-how-to-learn and group work (Nunan, 1989, p. 80). Settings vary 
from "individual work, pair work and group work to whole-class activities", and "settings should ideally vary throughout a course, so that learners can benefit from peer-group interaction as well as reflecting upon their learning in some solitude" (Corbett, 2003, p. 44), based on which discipline, classroom activities like pair and group discussion, role-play and reflective journal keeping can be adopted in this course.

The present author believes that input is of great importance in communicative tasks since it is what other aspects of communicative tasks like goal, activities, setting are based on. In this study, we focus on the "input" of the Audio-visual Course, that is, four groups of film clips on four cultural dimensions chosen from the Intercultural Film Database and questions and topics that are designed for one important classroom activity of discussion, both pair and group discussion, which immediately follows the students receiving the input.

\subsection{The Intercultural Film Database and the Four Cultural Dimensions}

The Intercultural Film Database is the source of the nineteen film clips chosen for this course. This is because, firstly, this film database is specifically for intercultural films, which is suitable for courses related to intercultural communication. Secondly, this medium-sized database of 142 films, made by 49 filmmakers of different nationalities and with a great variation of production dates ranging from the 1940s till recently, provides the teacher with multiple options. What's more, because the scenes representing the cultural dimensions are identified in this database, in practice, the Intercultural Film Database saves instructors a lot of time in narrowing down the scope of choice on one hand, and allows a quick location of pertinent scenes on the other hand.

The film clips in the Intercultural Film Database are analyzed according to twenty cultural dimensions that "derive mostly from the pattern variables evolved by American (Harvard) sociologists of the mid-twentieth century as a descriptive//analytic tool, not for measuring and quantifying human behavior" (email correspondence with Dr. Jarman, who directs the Intercultural Film Database), which include Individualism/Collectivism, Communication style: High/low context, Time Management (Monochromic-vs. Polychromic), and seventeen other cultural dimensions. It is worth mentioning that cultural dimensions here are only used to categorize film clips. It is not assumed that any cultural dimensions are associated more with one nationality, i.e., that one group of people is more likely to be individualist or collectivist. The cultural dimensions represent how people relate to each other in a certain setting. They are used to analyze behavior and attitudes.

However, this paper will only focus on four cultural dimensions that are taken from Hofstede (1986), that is, Individualism versus Collectivism, Power Distance, Uncertainty Avoidance, and Masculinity versus Femininity. This is because as Hofstede (ibid) states, "the four dimensions ... make theoretical sense".

Table 2 shows the four cultural dimensions that are covered in this elective Audio-visual College English course with a summary of Hofstede (1986) interpretations. 
Table 2. The four cultural dimensions (Hofstede, 1986)

\begin{tabular}{|c|c|}
\hline Cultural dimension & Interpretations \\
\hline $\begin{array}{l}\text { Individualism } \\
\text { /Collectivism }\end{array}$ & $\begin{array}{l}\text { Individualism is a characteristic of a culture that opposes } \\
\text { Collectivism (the word is used here in an anthropological, not a } \\
\text { political sense). Individualist cultures assume that any person looks } \\
\text { primarily after his/her own interest and the interest of his/her } \\
\text { immediate family (husband, wife and children). Collectivist cultures } \\
\text { assume that any person belongs to one or more tight "in-groups", } \\
\text { from which he/she cannot detach him/herself. A collectivist society } \\
\text { is tightly integrated; an individualist society is loosely integrated. }\end{array}$ \\
\hline Power Distance & $\begin{array}{l}\text { Power Distance is a characteristic of a culture that defines the extent } \\
\text { to which the less powerful persons in a society accept inequality in } \\
\text { power and consider it as normal. Inequality exists within any } \\
\text { culture, but the degree of it that is tolerated varies between one } \\
\text { culture and another. }\end{array}$ \\
\hline $\begin{array}{l}\text { Uncertainty } \\
\text { Avoidance }\end{array}$ & $\begin{array}{l}\text { Uncertainty Avoidance is a characteristic of a culture that defines the } \\
\text { extent to which people within a culture are made nervous by } \\
\text { situations which they perceive as unstructured, unclear, or } \\
\text { unpredictable situations which they therefore try to avoid by } \\
\text { maintaining strict codes of behavior and a belief in absolute truths. } \\
\text { Cultures with a strong sense of uncertainty avoidance are active, } \\
\text { aggressive, emotional, compulsive, security-seeking, and intolerant; } \\
\text { cultures with a weak uncertainty avoidance are contemplative, less } \\
\text { aggressive, unemotional, relaxed, accepting personal risks, and } \\
\text { relatively tolerant. }\end{array}$ \\
\hline $\begin{array}{l}\text { Masculinity/ } \\
\text { Femininity }\end{array}$ & $\begin{array}{l}\text { Masculinity is a characteristic of a culture that opposes Femininity. } \\
\text { Cultures of masculinity strive for maximal distinction between what } \\
\text { men are expected to do and what women are expected to do. They } \\
\text { expect men to be assertive, ambitious and competitive, to strive for } \\
\text { material success, and to respect whatever is big, strong, and fast. } \\
\text { They expect women to serve and to care for the non-material quality } \\
\text { of life, for children and for the weak. Feminine cultures, on the other } \\
\text { hand, define relatively overlapping social roles for the sexes, in } \\
\text { which, in particular, men need not be ambitious or competitive but } \\
\text { may go for a different quality of life than material success; men may } \\
\text { respect whatever is small, weak, and slow. In masculine cultures } \\
\text { political/organizational values stress material success and } \\
\text { assertiveness. In feminine cultures they stress other types of quality } \\
\text { of life, interpersonal relationships, and concern for the weak. }\end{array}$ \\
\hline
\end{tabular}

\subsection{Criteria for Choosing Film Clips from the Intercultural Film Database}

Films have already been used in language classrooms for intercultural education purposes (see, for example, Briam, 2010; Truong \& Tran, 2014; Xue \& Pan, 2012; Yang \& Fleming, 2013). As Sherman (2003, p. 2-3) points out, film presents us with all kinds of voices in different kinds of situations, providing a vast up-to-date linguistic resource of accents, vocabulary, grammar and syntax, and all kinds of discourse, which shows us how language in 
most of its uses and contexts, can be used for discussions, for writing assignments, as input for projects or the study of other subjects.

When using films in the classroom, as mentioned above, films should be appropriately selected and the teaching process should be managed closely and sensitively to guarantee that watching a film is not only for the purpose of entertainment, but also for language and intercultural learning (Parisi \& Andon, 2016; Xue \& Pan, 2012).

When choosing films and film clips for classroom use, several aspects need to be taken into consideration. First of all, as Sherman (2003, p. 5) claims, films should be "interesting, attractive to the eye and linguistically easy on the ear, or full of things that people say, do or handle in normal life". She proposed more specifically that when we choose films, we should choose films "with plenty of action between speech and a close connection between speech and action", as well as "with clear conventional story lines". Cartoons should be avoided, wherein "mouths, faces and body language are not as expressive as those of real people" (ibid, pp. 15-16) or they will hinder students' understanding. It is worth mentioning that Sherman stresses standard accents so she rules out regional films; however, in the context of this study which focuses on ICC in a context of English as a lingua franca, standard usage is not a criterion for choosing films, therefore, films with varieties of English are not excluded.

Besides, as Wood points out, what the students care most about a film is that the film is "dramatically powerful enough to move them" (1995, p. 43). This criterion should also be taken into consideration when teachers choose films and film clips.

What's more, familiarity is one aspect of consideration. From the author's point of view, on one hand, unfamiliarity creates a sense of appeal, on the other hand, the classic popular films that students may have already watched before make the digestion and understanding of the films much easier.

Finally, interest, appropriateness of content, length of sequence, independence of sequence, availability of related materials should also be kept in mind (Arcario, 1997, pp. 117-119).

Taken all the above-mentioned criteria into account, the general considerations to choose films for classroom use are summarized as follows:

1. The theme of the film should be suitable for classrooms.

2. Cultural contents should be accessible to the target class.

3. Cultural contrast is welcome.

Taking the goal of cultivating students' ICC through watching film clips chosen from the Intercultural Film Database as classroom input into consideration, the specific criteria for choosing films and film clips for this research are as follows:

1. Local accents, that is, varieties of English, e.g. Chinese accent, Indian accent, German-accent and so on are accepted, but articulation should be as clear as possible.

2. Film clips should present as many cultures as possible to allow more cultural 
comparison and contrast.

3. As many combinations of filmmakers, film settings and year of production as possible should be considered to allow multiculturalness.

4. The films/film clips should be self-contained and easy to follow.

5. Traditional cultural phenomena are accepted, and newly-appearing phenomena are also welcome, in that they may arouse great interest and heated discussion or debate, e.g. gender-neutral group. Of course, teachers have their own preference of certain topics and dislike of some others. But in order to demonstrate as many aspects of cultural phenomena as possible, teachers should try to be impartial when selecting the topics of films.

6. Concerning the familiarity of the films, a half-and-half doctrine is adopted, which means half of the films are those that the students are probably familiar with, and the other half are less familiar ones, although the present author believes that films that students are unfamiliar with may create a feeling of freshness, which is helpful in capturing the students' attention in the viewing process.

\subsection{Films and Film Clips Chosen for the Audio-visual College English Course}

Taking the above-listed criteria into account, nineteen film clips are chosen, among which two film clips are chosen from one same film to present two different cultural dimensions and one other clip is repeated in two different cultural dimensions.

Table 3 below shows the films and films clips chosen for each cultural dimension, the filmmakers, year of production, main settings as well as the cultures involved in each film.

Table 3. Filmmakers, main settings and cultures involved in each film

\begin{tabular}{|c|c|c|c|c|}
\hline \multicolumn{5}{|c|}{ Individualism/Collectivism } \\
\hline Name & Producer(s) & $\begin{array}{l}\text { Year of } \\
\text { Production }\end{array}$ & Main setting(s) & $\begin{array}{l}\text { Cultures Involved } \\
\text { and Contrasted }\end{array}$ \\
\hline Desert Flower & $\begin{array}{l}\text { UK/Germany } \\
\text { /Austria }\end{array}$ & 2009 & $\begin{array}{l}\text { Somali/ } \\
\text { London }\end{array}$ & Somali and British \\
\hline English Vinglish & India & 2012 & New York & $\begin{array}{l}\text { Indian, French and } \\
\text { American }\end{array}$ \\
\hline Fools Rush In & USA & 1997 & Los Angels & $\begin{array}{l}\text { Mexican, } \\
\text { Mexican-American } \\
\text { and American }\end{array}$ \\
\hline $\begin{array}{l}\text { Where Angels } \\
\text { Fear to Tread }\end{array}$ & UK & 1991 & Italy & British and Italian \\
\hline $\begin{array}{l}\text { A Thousand Years } \\
\text { of Good Prayers }\end{array}$ & USA & 2007 & USA & $\begin{array}{l}\text { Chinese-American, } \\
\text { American, Chinese } \\
\text { and Russian }\end{array}$ \\
\hline \multicolumn{5}{|c|}{ Femininity/Masculinity } \\
\hline $\begin{array}{l}\text { Coming } \\
\text { America }\end{array}$ & USA & 1998 & US & $\begin{array}{l}\text { American, } \\
\text { Afro-American, } \\
\text { and African }\end{array}$ \\
\hline
\end{tabular}




\begin{tabular}{|c|c|c|c|c|}
\hline Japanese Story & Australia & 2003 & Australia & $\begin{array}{l}\text { Australian and } \\
\text { Japanese }\end{array}$ \\
\hline Urga & $\begin{array}{l}\text { France/Sovie } \\
\text { t Union }\end{array}$ & 1991 & Russia & $\begin{array}{l}\text { Russian, } \\
\text { Mongolian and } \\
\text { Chinese }\end{array}$ \\
\hline A World Apart & $\begin{array}{l}\text { UK/Zimbab } \\
\text { we }\end{array}$ & 1988 & South African & $\begin{array}{l}\text { White South } \\
\text { African and Black } \\
\text { South African }\end{array}$ \\
\hline English Vinglish & USA & 2012 & New York & $\begin{array}{l}\text { Indian, French and } \\
\text { American }\end{array}$ \\
\hline \multicolumn{5}{|l|}{ Power Distance } \\
\hline Pushing Hands & USA/Taiwan & 1992 & USA & $\begin{array}{l}\text { American, } \\
\text { Chinese-American } \\
\text { and Chinese }\end{array}$ \\
\hline Live and Become & France & 2005 & Israel & $\begin{array}{l}\text { Israeli Jewish and } \\
\text { Ethiopian }\end{array}$ \\
\hline $\begin{array}{ll}\text { Mao's } & \text { Last } \\
\text { Dancer } & \end{array}$ & Australia & 2009 & $\begin{array}{ll}\text { US } & \text { and } \\
\text { Australia } & \end{array}$ & $\begin{array}{l}\text { American and } \\
\text { Chinese }\end{array}$ \\
\hline $\begin{array}{l}\text { Shouf shouf } \\
\text { bahibi }\end{array}$ & $\begin{array}{l}\text { the } \\
\text { Netherlands }\end{array}$ & 2004 & $\begin{array}{l}\text { The } \\
\text { Netherlands }\end{array}$ & $\begin{array}{l}\text { Moroccan } \\
\text { (Netherlands), } \\
\text { Dutch and } \\
\text { Moroccan }\end{array}$ \\
\hline $\begin{array}{l}\text { The Year of } \\
\text { Living } \\
\text { Dangerously }\end{array}$ & Australia & 1982 & Indonesia & $\begin{array}{l}\text { Indonesian, } \\
\text { Australian and } \\
\text { British }\end{array}$ \\
\hline \multicolumn{5}{|c|}{ Uncertainty Avoidance } \\
\hline $\begin{array}{l}\text { One Day in } \\
\text { Europe }\end{array}$ & $\begin{array}{l}\text { Germany/Spa } \\
\text { in }\end{array}$ & 2005 & Istanbul & $\begin{array}{l}\text { Turkish } \\
\text { German }\end{array}$ \\
\hline $\begin{array}{l}\text { Chinese } \\
\text { Take-away }\end{array}$ & Argentina & 2011 & Argentina & $\begin{array}{l}\text { Argentina and } \\
\text { Chinese }\end{array}$ \\
\hline Fools Rush In & USA & 1997 & Los Angels & $\begin{array}{l}\text { Mexican, } \\
\text { Mexican-American } \\
\text { and American }\end{array}$ \\
\hline $\begin{array}{l}\text { Schultze Gets the } \\
\text { Blues }\end{array}$ & Germany & 2003 & German & $\begin{array}{l}\text { German } \\
\text { American }\end{array}$ \\
\hline Sayonara & USA & 1957 & Japan & $\begin{array}{l}\text { Japanese } \\
\text { American }\end{array}$ \\
\hline
\end{tabular}

Basic information about the nineteen film clips chosen for this research is as follows (one film clip is repeated for two different cultural dimensions): 
Table 4. Introduction to the twenty film clips (extracted from the website of the Intercultural Film Database)

\begin{tabular}{|c|c|c|c|}
\hline Film & Film clip & Timing & Description \\
\hline $\begin{array}{l}\text { Desert } \\
\text { Flower }\end{array}$ & $\begin{array}{l}\text { Arranged } \\
\text { marriage }\end{array}$ & $\begin{array}{l}00: 39: 0 \\
7- \\
00: 40: 0 \\
4\end{array}$ & $\begin{array}{l}\text { Waris joins her dad and an old looking man who are } \\
\text { sitting around a campfire. She is told that she is to } \\
\text { marry the man the following day. }\end{array}$ \\
\hline $\begin{array}{l}\text { English } \\
\text { Vinglish }\end{array}$ & $\begin{array}{l}\text { No more } \\
\text { English } \\
\text { Vinglish }\end{array}$ & $\begin{array}{l}01: 42: 4 \\
0-01: 4 \\
4: 45\end{array}$ & $\begin{array}{l}\text { Because she was not there when her son got injured, } \\
\text { Shashi tells her niece Radha that she has decided to } \\
\text { quit the English course. Radha tries to persuade her to } \\
\text { finish the course. But Shashi does not want to neglect } \\
\text { her family again. }\end{array}$ \\
\hline $\begin{array}{l}\text { Fools } \\
\text { Rush In }\end{array}$ & $\begin{array}{l}\text { First } \\
\text { impressio } \\
\text { ns }\end{array}$ & $\begin{array}{l}00: 26: 0 \\
1- \\
00: 28: 0 \\
5\end{array}$ & $\begin{array}{l}\text { In order for Isabel to introduce Alex to the family as } \\
\text { her boyfriend, they go to the Fuentes's dinner party. } \\
\text { Alex is shocked when he sees the big extended family } \\
\text { milling about in the garden, and he later on admits that } \\
\text { he doesn't meet his own family all that often. }\end{array}$ \\
\hline $\begin{array}{l}\text { Where } \\
\text { Angels } \\
\text { Fear to } \\
\text { Tread }\end{array}$ & $\begin{array}{l}\text { An Italian } \\
\text { birth }\end{array}$ & $\begin{array}{l}00: 35: 0 \\
0-00: 3 \\
7: 00\end{array}$ & $\begin{array}{l}\text { Here we see the moment that everybody is waiting for } \\
\text { - for the child of Gino and Lilia to be born. While } \\
\text { waiting, the men entertain themselves by playing cards } \\
\text { in the pub, while the women pray together and watch } \\
\text { over after Lilia, so as to be there to help when she } \\
\text { starts to give birth to the baby. }\end{array}$ \\
\hline $\begin{array}{l}\text { A } \\
\text { Thousan } \\
\text { d Years } \\
\text { of Good } \\
\text { Prayers } \\
\end{array}$ & $\begin{array}{l}\text { Retireme } \\
\mathrm{nt} \text { home }\end{array}$ & $\begin{array}{l}00: 54: 3 \\
1-00: 5 \\
5: 30\end{array}$ & $\begin{array}{l}\text { Mr. Shi is waiting in the park for Madam, but the old } \\
\text { woman doesn't show up anymore. Instead, a friend of } \\
\text { hers comes, and tells Mr. Shi that Madam has been } \\
\text { sent to a retirement home by her son. }\end{array}$ \\
\hline $\begin{array}{l}\text { Coming } \\
\text { to } \\
\text { America }\end{array}$ & $\begin{array}{l}\text { Let us say } \\
\text { one } \\
\text { million } \\
\text { American } \\
\text { dollars }\end{array}$ & $\begin{array}{l}1: 35: 06 \\
-\quad 1: 35: \\
55\end{array}$ & $\begin{array}{l}\text { After speaking with Lisa and making it clear to her } \\
\text { that she is not the right woman for a prince, the King } \\
\text { tries to "compensate" for any "inconvenience" caused } \\
\text { Mr. McDowell by offering him a million American } \\
\text { dollars. McDowell's reaction is very emotional-it } \\
\text { seems to him that the King is attempting to buy his } \\
\text { daughter. }\end{array}$ \\
\hline $\begin{array}{l}\text { Japanese } \\
\text { Story }\end{array}$ & $\begin{array}{l}\text { Sandy } \\
\text { and } \\
\text { Hiromitsu } \\
\text { meet }\end{array}$ & $\begin{array}{l}00: 11: 3 \\
0-00: 1 \\
2: 58\end{array}$ & $\begin{array}{l}\text { Sandy picks Hiromustu up at the airport. Sandy has to } \\
\text { load Hiromitsu's luggage for him and is slightly } \\
\text { surprised that he does not do it himself, being a man. }\end{array}$ \\
\hline Urga & $\begin{array}{l}\text { Pagma } \\
\text { and } \\
\text { Marina }\end{array}$ & $\begin{array}{l}00: 59: 0 \\
0-01: 0 \\
1: 21\end{array}$ & $\begin{array}{l}\text { The scene begins when Gombo has already gone to the } \\
\text { city and Pagma has to catch the horses, which have } \\
\text { run away, on her own. She seems to be in no kind of } \\
\text { distress, but is very capable of handling the situation } \\
\text { all by herself. Immediately afterwards in the film we } \\
\text { see how Sergei comes home to his wife Marina. She is } \\
\text { crying and very nervous because he hasn't called her } \\
\text { for two days, so he has to comfort her and to calm her }\end{array}$ \\
\hline
\end{tabular}




\begin{tabular}{|c|c|c|c|}
\hline & & & down. \\
\hline $\begin{array}{l}\text { A World } \\
\text { Apart }\end{array}$ & $\begin{array}{l}\text { Molly } \\
\text { wants to } \\
\text { see } \\
\text { Yvonne }\end{array}$ & $\begin{array}{l}00: 48: 3 \\
7-00: 5 \\
2: 25\end{array}$ & $\begin{array}{l}\text { Molly is waiting for Yvonne to call her as she } \\
\text { promised in school that very morning, but the phone } \\
\text { remains silent. She takes the initiative and tries to call } \\
\text { her, but they won't let her talk to Yvonne. She sends } \\
\text { her sisters away, climbs out of the window and runs } \\
\text { over to Yvonne's house. There, they won't let her in, } \\
\text { and a moment later Yvonne's father arrives in his car. } \\
\text { He is very rude to her, and grabs her by the arm in } \\
\text { order to drag her into the car and bring her home. He } \\
\text { told her that she should leave Yvonne alone. Home } \\
\text { again, Molly falls into Elsie's arms in desperation. }\end{array}$ \\
\hline $\begin{array}{l}\text { Pushing } \\
\text { Hands }\end{array}$ & $\begin{array}{l}\text { Continuat } \\
\text { ion of the } \\
\text { family } \\
\text { name }\end{array}$ & $\begin{array}{l}00: 15: 4 \\
3- \\
00: 16: 3 \\
0\end{array}$ & $\begin{array}{l}\text { Mr. Chu, as the family elder, checks his grandson } \\
\text { Jeremy's health "below the waist" to ensure the } \\
\text { continuation of his family line and name. Martha is } \\
\text { taken aback by his straightforwardness. Mr. Chu } \\
\text { doesn't realize why Martha grabs Jeremy away from } \\
\text { him. Alex tells him (and lies) that she is afraid about } \\
\text { Jeremy catching a cold. }\end{array}$ \\
\hline $\begin{array}{l}\text { Live and } \\
\text { Become }\end{array}$ & $\begin{array}{l}\text { Schlomo' } \\
\text { s new } \\
\text { family }\end{array}$ & $\begin{array}{l}00: 31: 0 \\
8-00: 31 \\
: 48\end{array}$ & $\begin{array}{l}\text { After Hana, Schlomo's foster mother, succumbs to her } \\
\text { disease, Schlomo experiences the loneliness of his } \\
\text { existence in Israel and is devastated by his situation. } \\
\text { The director and other teachers decide to send } \\
\text { Schlomo to live in a Jewish foster family. His foster } \\
\text { parents Yäel and Yoram pick him up at the boarding } \\
\text { school and take him to their home, where he is } \\
\text { introduced to the rest of the family. When Schlomo } \\
\text { shakes his new grandfather's (Yoram's father's) hand, } \\
\text { he does not look into his eyes. The grandfather says to } \\
\text { Schlomo that he is very polite and explains that in his } \\
\text { culture they also refused to look into a stranger's eyes. }\end{array}$ \\
\hline $\begin{array}{l}\text { Mao's } \\
\text { Last } \\
\text { Dancer }\end{array}$ & $\begin{array}{l}\text { The } \\
\text { president }\end{array}$ & $\begin{array}{l}00: 24: 5 \\
0-00: 2 \\
5: 20\end{array}$ & $\begin{array}{l}\text { Li says that he "loves" Chairman Mao, and is amazed } \\
\text { that his American friend Dilworth can speak so } \\
\text { disrespectfully of the U.S.A. President. Isn't he scared } \\
\text { to do so? }\end{array}$ \\
\hline $\begin{array}{l}\text { Shouf } \\
\text { shouf } \\
\text { bahibi }\end{array}$ & $\begin{array}{l}\text { The little } \\
\text { blackmail } \\
\text { er }\end{array}$ & $\begin{array}{l}00: 19: 5 \\
0-00: 2 \\
1: 05\end{array}$ & $\begin{array}{l}\text { In this scene we see Driss, Ap's younger brother, } \\
\text { printing a photograph of a Moroccan girl who is not } \\
\text { wearing her headscarf as she is supposed to. Driss } \\
\text { blackmails her at school with the photograph: she must } \\
\text { pay him five Euros or he will show the photo to her } \\
\text { father. The girl does not hesitate to give him the } \\
\text { money because she is aware of the consequences that } \\
\text { will otherwise follow. Driss continues to take secret } \\
\text { snapshots, now turning his lens on some Moroccan } \\
\text { girls in the girls' toilets who are not only not wearing } \\
\text { headscarves but are actually putting on make-up. } \\
\text { While he is photographing, however, a teacher sneaks } \\
\text { up and catches him. }\end{array}$ \\
\hline
\end{tabular}




\begin{tabular}{|c|c|c|c|}
\hline $\begin{array}{l}\text { The Year } \\
\text { of Living } \\
\text { Dangero } \\
\text { usly }\end{array}$ & $\begin{array}{l}\text { "Don't } \\
\text { call me } \\
\text { boss" }\end{array}$ & $\begin{array}{l}00: 10: 1 \\
6- \\
00: 10: 2 \\
2\end{array}$ & $\begin{array}{l}\text { Guy tells his assistant: "Don't call me boss". The } \\
\text { assistant is very astonished and insecure. }\end{array}$ \\
\hline $\begin{array}{l}\text { One Day } \\
\text { in } \\
\text { Europe }\end{array}$ & $\begin{array}{l}\text { The } \\
\text { second } \\
\text { interrogat } \\
\text { ion }\end{array}$ & $\begin{array}{l}00: 33: 2 \\
8- \\
00: 34: 1 \\
5\end{array}$ & $\begin{array}{l}\text { Rokko is brought into an interrogation room where he } \\
\text { sits down with a female officer for a preliminary } \\
\text { interview and then talks to her superior. After the } \\
\text { interrogation they make him look at dozens of pictures } \\
\text { of criminals in order to identity his muggers and he is } \\
\text { left alone in the room-locked in. He phones Celal for } \\
\text { help. }\end{array}$ \\
\hline $\begin{array}{l}\text { Chinese } \\
\text { Take-aw } \\
\text { ay }\end{array}$ & $\begin{array}{l}\text { First } \\
\text { encounter }\end{array}$ & $\begin{array}{l}00: 14: 2 \\
7-00: 2 \\
1: 20\end{array}$ & $\begin{array}{l}\text { Roberto and Jun see each other for the first time: } \\
\text { Roberto is having a little meal near the airport when } \\
\text { Jun gets thrown out of a taxi. Jun directly walks } \\
\text { towards Roberto and asks for his help, in Chinese. } \\
\text { Roberto does not understand what this strange man is } \\
\text { saying, but he decides to help. As they drive, Jun gets } \\
\text { travel sick and has to throw up. Roberto gets angry } \\
\text { and leaves Jun at a bus stop. But later on, as heavy rain } \\
\text { starts, he gets a bad conscience and drives to the bus } \\
\text { stop again to pick Jun up. }\end{array}$ \\
\hline $\begin{array}{l}\text { Fools } \\
\text { Rush In }\end{array}$ & $\begin{array}{l}\text { Angry } \\
\text { Daddy }\end{array}$ & $\begin{array}{l}00: 40: 5 \\
3-00: 4 \\
1: 50\end{array}$ & $\begin{array}{l}\text { Isabel's father Tomas drives to the construction site } \\
\text { after finding out about his daughter's marriage. He } \\
\text { jumps out of his car and, shouting aggressively, } \\
\text { threatens Alex with a baseball bat. }\end{array}$ \\
\hline $\begin{array}{l}\text { Schultze } \\
\text { Gets the } \\
\text { Blues }\end{array}$ & $\begin{array}{l}\text { Who } \\
\text { wants to } \\
\text { go to the } \\
\text { USA? }\end{array}$ & $\begin{array}{l}00: 13: 0 \\
4-\quad 00: \\
15: 08\end{array}$ & $\begin{array}{l}\text { Schultze and his friends are informed that someone } \\
\text { will be invited to go to the USA to play music at a } \\
\text { festival. Schultze says he is not interested: "Da mach } \\
\text { ich nicht mit! (I will not go!)" }\end{array}$ \\
\hline Sayonara & $\begin{array}{l}\text { You're } \\
\text { obligated } \\
\text { to me! }\end{array}$ & $\begin{array}{l}01: 43: 2 \\
8-01: 4 \\
7: 19\end{array}$ & $\begin{array}{l}\text { Hana-Ogi and Lloyd have a conversation about their } \\
\text { future plans, especially marriage. Lloyd is thinking } \\
\text { about leaving the military and getting a job in Japan. }\end{array}$ \\
\hline
\end{tabular}

\section{Questions and Topics for Discussion for Each Cultural Dimension}

Immediately after watching the film clips for one cultural dimension, classroom activity of discussion, both pair and group discussion, is conducted, in which students listen, perform, interact, negotiate and develop group work. Discussion also enables the students to have a deeper understanding of the classroom input.

In order to initiate heated discussion, several questions and topics for each cultural dimension are proposed (Table 5).

Table 5. Questions and topics for discussion for each cultural dimension

\begin{tabular}{|l|l|}
\hline $\begin{array}{l}\text { Cultural } \\
\text { dimension }\end{array}$ & Questions and topics \\
\hline
\end{tabular}


\begin{tabular}{|l|l|l|}
\hline Individualism & 1. Muslim women and men are happy to have their marriages arranged for
\end{tabular} /Collectivism them. This is impossible to accept by many "Western" oriented people (Huber-Kriegler, et al., 2003, p. 40). Discuss the arranged marriage in Desert Flower. In what kind of society, i.e., the society of Individualism or the society of Collectivism is it likely that an arranged marriage will occur? What is the situation in your own country? Would you accept an arranged marriage? Why or why not?

2. Research regularly shows that, on average, women do much more of the household chores in most families. Cleaning, shopping and cooking are routinely done by women, while men often reserve their skills in this area for "special occasions". The image of the man of the house in an apron, running the barbecue for a happy crowd is stereotypical, but none the less real for that. Preparing the two or three ordinary meals on an ordinary day to sustain a family is usually still the domain of the women (ibid, p. 43). Discuss the characteristics of the role of men and women in an Individualist/Collectivist society. What kind of society is India? Do you think that in a collectivist society, normally a woman's personal welfare can and should be sacrificed for the welfare of the whole family?

Femininity 1 . Discuss women's role in your country. Are women in your country like /Masculinity the heroines in Japanese Story and Urga or the heroine in English Vinglish? How do you like women to behave?

2. In his extensive writing on his native India, Pittu Laungani indicates that there are significant differences in the socialization processes of boys and girls in India. To be sure, writes Laungani, boys are privileged - so much so that in impoverished homes, of which there are many, a larger share of food is given to the male children, and they are also fed first by the family members. Laungani notes that the birth of a male child is considered a blessing because it ensures the continuation of the family name (Neuliep, 2012 , p. 225). How are boys and girls treated in the countries that you know?

3. What characteristics do you associate with Masculinity and Femininity, e.g., acts as a leader, analytical, assertive, athletic, competitive, dominant, strong personality and affectionate, childlike, compassionate, gentle, loyal, shy, etc.? (Chesbro, et al., 2014, p. 334)

\begin{tabular}{l|l} 
Power & 1 . Do you respect your superior like the hero in Mao's Last Dancer or do
\end{tabular} Distance you dare to challenge your superior and treat him/her as your equal?

2. Sandra is a fun-loving teacher teaching in the LINC (Language Instruction for Newcomers to Canada) program. At the beginning of every course, she explains the classroom and school guidelines, including the rule about being late. After about a week and a half, one of her students started to arrive late for class every morning. Sandra likes to treat the thing in a light-hearted manner, and so when the students walked in late one morning, Sandra said "good evening" to her and everyone laughed. Sandra had done this before with other students. The student ignored Sandra and went and sat down. Sandra felt a little annoyed and so she asked the student why she was late. The student then yelled at Sandra and said, "You don't talk to me like that!" Sandra told her that she should apologize for being late. Later, Sandra approached her privately and apologized to her even though she felt that the student should apologize first. The student also apologized but later stopped 


\begin{tabular}{|l|l|}
\hline Uncertainty & $\begin{array}{l}\text { coming to class altogether (Apedaile \& Schill, 2008, p. 55). How would you } \\
\text { resolve this conflict? }\end{array}$ \\
\hline Avoidance & $\begin{array}{l}\text { live with your boyfriend or girlfriend? If you were the heroine in Sayonara, } \\
\text { would you accept the hero's proposal, marrying him and going to the U.S.A } \\
\text { with him? } \\
\text { 2. Mark entered his LINC (Language Instruction for Newcomers to Canada) } \\
\text { class on the first day and introduced himself to the class. The first lesson } \\
\text { was designed to work on all four skills and to give students the chance to } \\
\text { get to know their teacher. Mark began by telling the students that he, too, } \\
\text { was an immigrant to Canada and that he was going to share his biography } \\
\text { with the class. Their first assignment was to ask him questions and take } \\
\text { notes about what they heard. Next, they had to write several paragraphs } \\
\text { about him and hand it in later that week. On the day that it was due, all the } \\
\text { students had done the work except for one. Mark asked her why she had not } \\
\text { done her homework, and she answered that she did not need to know about } \\
\text { him. Mark explained that the assignment was designed to work on a variety } \\
\text { of specific English skills that she needed to improve her ability to } \\
\text { communicate in English. After that, she did not really participate in class. } \\
\text { She did her own work and paid attention only when there was something } \\
\text { that interested her (ibid, p. 54). How would you deal with this situation? } \\
\text { 3. Len teaches the evening TOEFL (Test of English as a Foreign Language) } \\
\text { class. One day there was a conflict between a student who wanted to do } \\
\text { more listening practice in class and a student who wanted to focus only on } \\
\text { grammar. The next day, one of the two students came to Len's office to talk } \\
\text { to him about the class. She told him that she thought they had studied } \\
\text { enough grammar and that they needed more listening practice. She assured } \\
\text { him that she was not trying to tell him what to teach. A week later she } \\
\text { invited Len to come to her home so that she could show him something. He } \\
\text { did not go. Then she sent him an e-mail, thanking him for his teaching and } \\
\text { complimenting him on his looks. This made him very uncomfortable, so he } \\
\text { made a conscious attempt to avoid her outside of class (ibid, p. 56). Discuss } \\
\text { this situation. }\end{array}$ \\
\hline
\end{tabular}

\section{Implication}

When this elective Audio-visual College English course is over, students' ICC can be assessed in some ways, which is a further aspect of the research, and consequently the effectiveness of this course can be tested. If the outcome of the course is desirable, this course can be adopted by other College English teachers at a larger scale.

During the process of teaching, adjustments and changes can be made by College English teachers so that this course may become more effective and interesting. 


\section{Acknowledgement}

Thanks go to Professor John Corbett, of the University of Macau, for his invaluable comments on an earlier draft of this piece and the final proofreading. I am also very grateful to the anonymous reviewer and the editor for their insightful suggestions.

\section{References}

Aguilar, M. J. C. (2002). Intercultural communicative competence: A step beyond communicative competence. ELLA, 3, 85-102.

Apedaile, S., \& Schill, L. (2008). Critical incidents for intercultural communication: An interactive tool for developing awareness, knowledge, and skills - Facilitator and activity

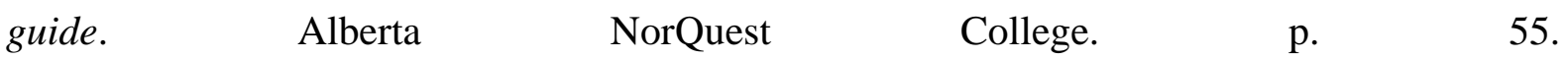
https://www.norquest.ca/NorquestCollege/media/pdf/centres/intercultural/CriticalIncidentsBo oklet.pdf

Arcario, P. (1997). Criteria for selecting video materials. In S. Stempleski, \& P. Arcario (Eds), Video in second language teaching: using, selecting, and producing video for the classroom (pp. 109-121). Teaching of English to Speakers of Other Languages, INC.

Briam, C. (2010). Outsourced: Using a comedy film to teach intercultural communication. Business Communication $\quad$ Quarterly, 383-398. http://www.brown.uk.com/teaching/intercultural/briam.pdf

Byram, M. (1997). Teaching and assessing intercultural communicative competence. New York: Multilingual Matters. p. 71.

Cai, J. G. (2014). CET from the perspective of national strategy The use of film-based material for an adult English language course in Brazil: Turning left or right? Foreign Language Education, 35(2), 40-44. http://en.cnki.com.cn/Article_en/CJFDTOTAL-TEAC201402011.htm

Chesbro, J. W., McMahan, D. T., Russett, P. Schumacher, E. J., Wu, J. L. (2014). The masculine-feminine construct in cross-cultural research: The emergence of a transcendent global culture. In M. K. Asante, Y. Miike, \& J. Yin (Eds.), The global intercultural communication reader (pp. 321-338). New York: Routledge.

Corbett, J. (2003). An intercultural approach to English language teaching. Clevedon: Multilingual Matters. pp. 43-45.

Fantini, A. E. (2005). About intercultural communicative competence: A construct. Retrieved from http://federationeil.org/documents/AppendixE.pdf.

Hofstede, G. (1986). Cultural differences in teaching and learning. International Journal of Intercultural Relations, $\quad 11, \quad 301-320$. http://www.sciencedirect.com/science/article/pii/0147176786900155

$\mathrm{Hu}$, Z. L. (2002). 中国英语教学中的“低效”问题The problem of inefficiency in English teaching in China. 国 外外语 教 学 FLTA, 4, 3-6. http://www.24en.com/study/mingshi/2006-05-25/51551.html

Huber-Kriegler, M., Lazar, I. \& Strange, J. (2003). Mirrors and windows: An intercultural 
communication textbook. Strasbourg: Council of Europe Publishing. p. 40. archive.ecml.at/documents/pub123ae2003_huberkriegler.pdf

Intercultural Film Database. Retrieved from: http://www.uni-hildesheim.de/interculturalfilm/ Liu, G. Q. (2012). Paying much attention to College English reform to improve the quality of College English teaching. Foreign Language Teaching and Research (bimonthly), 44(2), 279-282.

Matsuda, A. (2012). Teaching materials in EIL. In L. Alsagoff, S. L. McKay, G. Hu, \& W. A. Renandya (Eds.), Principles and practices for teaching English as an international language (pp. 168-185). New York: Routledge.

Ministry of Education, PRC. (2003). English Curriculum Requirements for Senior High School (Experiential Version). Beijing: Peoples' Education Press.

Ministry of Education, PRC. (2011). English Curriculum Requirements for Compulsory Education. Beijing: Beijing Normal University Publications Group.

Neuliep, J. W. (2012). Intercultural communication: A contextual approach. California: Sage Publications, Inc. p. 225.

Nunan, D. (1989). Designing tasks for the communicative classroom. Cambridge: Cambridge University Press. p. 11, 80.

Parisi, L. L., \& Andon, N. (2016). The use of film-based material for an adult English language course in Brazil. Trab. Ling. Aplic., Campinas, n(55.1), jan./abr., 101-128. http://www.scielo.br/pdf/tla/v55n1/0103-1813-tla-55-01-00101.pdf

Sercu, L. (2004). Assessing intercultural competence: a framework for systematic test development in foreign language education and beyond. Intercultural Education, 15(1), 73-90. http://eric.ed.gov/?id=EJ694734

Shanghai Educational Committee. (2013). College English Teaching Reference Framework (For Trial Implementation). http://www.233.com/cet4/dagang/20130326/150028400-2.html

Sherman, J. (2003). Using authentic video in the language classroom. Cambridge: Cambridge University Press.

$\mathrm{Su}, \mathrm{D}$. F. (2013). 关于我国外语教育规划与布局的思考 Consideration of the plan of foreign language education in China. Foreign Language Teaching and Research (bimonthly), 45(3), 426-435. http://www.cnki.com.cn/Article/CJFDTOTAL-WJYY201303013.htm

Truong, L. B., \& Tran, L. T. (2014). Students' intercultural development through language learning in Vietnamese tertiary education: a case study on the use of film as an innovative approach. Language and Intercultural Communication, 14(2), 207-225. http://www.tandfonline.com/doi/abs/10.1080/14708477.2013.849717

Wang, D. F. (2007). 中国语言生活状态报告 Report on the language status in China. Press conference of the Ministry of Education.

Wang, S. R., \& Wang, H. X. (2011). On the state of College English teaching in China and its future development. $\quad F L C, \quad 8(5)$, 4-17. http://wenku.baidu.com/view/c7ea4ed726fff705cc170acb.html

Wen, Q. F. (2012b). Challenges faced by College English and strategies: from the perspective of curriculum. Foreign Language Teaching and Research (bimonthly), 44(2), 283-292. 


\section{Macrothink}

http://wenku.baidu.com/link?url=Q00wEwD8FdWBHAihH2Y8j3Bnf6AH5NPyocGvn81nYs DblxfvNlxG69CfO0Fn9WYwjgFBHYnOOZGtbGQ_hnH7ZH-SGfKm4T3ELCMmTtXqLha Wood, D. J. (1995). Film communication theory and practice in teaching English as a foreign language. Lewiston: The Edwin Mellen Press.

Xue, J., \& Pan, Q. (2012). The effects of film appreciation on improving the students' Intercultural Communication Competence. Theory and Practice in Language Studies, 2(8), 1741-1745. http://www.academypublication.com/issues/past/tpls/vol02/08/27.pdf

Yang, L. H., \& Fleming, M. (2013). How Chinese college students make sense of foreign films and TV series: implications for the development of intercultural communicative competence through online exchanges. CALICO Journal, 28(2), 392-419. http://www.tandfonline.com/doi/full/10.1080/09571736.2013.836347?src=recsys

\section{Copyright Disclaimer}

Copyright for this article is retained by the author(s), with first publication rights granted to the journal.

This is an open-access article distributed under the terms and conditions of the Creative Commons Attribution license (http://creativecommons.org/licenses/by/3.0/). 